\title{
Mughal Men's Head Ornaments with an Emphasize on Turban Ornaments and their Connection with European Aigrette
}

\author{
Muhammad Ahsan Bilal \\ Lecturer \& Ph.DScholar \\ Research Center \\ University College of Art \& Design, \\ University of Punjab, Lahore
Sonia Nasir Khan
Lecturer \\ Department of Art \& Design \\ The Women University Multan
}

\begin{abstract}
Jewelry is main aspect of dressing and Mughal Jewelry is a fascinating theme to explore. Its styles can be traced through the paintings that clearly give accurate information of the style and variety of ornaments that were used during the seventeenth and eighteenth centuries. Jewelry is considered the feminine adornment part but miniature shows the beautiful ornamentation of Mughal emperors also with variation in sizes and design. This article discusses the Mughalmale head ornaments and study is focused on the turbanornamentations. As man's turban is his sacrosanct property and variety of turban ornaments were used by Mughals. This paper is an attempt to understand and examine that how the Mughal turban ornament develops from simple feather to piece of complex jewelry designs and how other culture helps in its development. Why Mughal emperors worn such gemstones in headdress and which techniques were used for its decoration? Is there any specific reason of using such gemstones or just for ornamentations purposes? In the end it concludes that sarpech shapes helps in the development of European aigrette and became a part of European jewelry that later helped in the modification of turban ornaments and Euro-Indian sarpech-aigrette appeared with more delicate style.
\end{abstract}

Keywords: Turban, Ornament, Mughals, Culture, Development.

\section{Introduction}

The richest development period of traditional jewelry in India is during the Mughal times $\left(16^{\text {th }}\right.$ $19^{\text {th }}$ centuries). The new style flourished much under Akbar, Jahangir and Shāhjahān and under Shāhjahān; the metropolitan style was unified as never before. The craftsmen who worked for them combined Indian (different regional center styles), Persian and later European elements along with big stones of gems (not cut but tumbled cabochons or beads to keep the size) to 
produce a dazzling array of innovative jewelry designs. Untracht (1997) believes that provincial workshops not only preserved Mughal jewelry forms and techniques, but they also developed new ones. Particularly distinctive are the many different regional styles of enameling, an important aspect of later Indian jewelry from Jaipur, Delhi, and Lucknow, and other centers. Deccan and Rajput and later European influence. Gelder (2018) explains the skills required to produce jewelry include goldsmithing, smelting, enameling and stringing as well as stone cutting and polishing. Variations in patronage, region, materials and period preferences certainly contributed to the rich variety of later art. Unfortunately, most of the imperial Mughal jewels were dispersed after 1739 when Nadir Shah sacked Delhi. Many of these precious stones later became the part of the court jewels of Iran; a few were presented to Russia by Nadir Shah in 1741 (Marshman 1863).

\section{Mughal Men's Head Ornaments:}

There are varieties of Head ornaments worn by Mughal men (fig: 1) Bali is a round earring like in shape just like gold wire like hoop, laced with two pearls and parted by either a ruby or emerald. Kalghi is black heron's feather and at its tip a pearl is suspended, its stem bound with either gold or silver wire, and worn projecting backward in the turban, normally behind the sarpech. Mukut is another ornament worn by Mughal men's. It's a multipeaked crown in precious metal frequently ornamented with gemstones and enamel. Although seldom in actual use during early Mughal times, the mukut was often depicted in miniature paintings symbolically hovering over the head of a ruler. In the late Mughal period, mukuts achieved a state of great elaboration and were worn by both the Mughal emperor and provincial rulers Untracht (1997). Sarpech is also an ornament. It's a bunch of jewels worn either on the frontal or on the side of turban. Its Persian name is Jiqa. While Turra is the turban embellishment, mostly in a bird form and a multi-layered tassel of pearl is suspended from its beak. These strands end contains the emerald along with tinsel tassel of gold.

\section{Turban / Headgear}

The turban, because of its association with the Prophet, took on a religious signification. (Dankoff 2017). In Islam the turban came to be an emblem of dignity (Kister 2000, 223, n. 22) and absence of headgear depicts the loss of control, freedom and even loss of life. The depiction of headgear as norm also appeared in Islamic paintings.

Headgears before Mughal: In ancient India (From earliest 12th century): Vedic era followed by the Pauranic or the classical in which men worn, the scarf or uttariya, as the turban. In the 
Sultanate Period (12-16 $6^{\text {th }}$ century): Indo-Persian style appears. The short turbans normally did not more than five or six forearms) and skull caps known as kulah were common objects to wear. Ragamala paintings that were produced in Marwar during $16^{\text {th }}$ century for the Hindu patrons before Mughal period shows a small angular turban. (Pooja 2016)

Both men and women are adorned with jewelry like crowns, forehead ornaments, necklaces and bangles, armlets, waist girdles and anklets etc. Islamic Mongol officials and courtiers have a unique headdress with feather (Blair 2005). Dervish have cone-shaped turban known as qalansuwa and qadis head shawl (Stillman 2000). While Mamluks headgear, contains red or violet color fur hat zamat (Fuess 2008). Later Ottomans ornamented their turbans with flowers (Nacipoglu 1997, 43). Headgear as fashion increased during Safavis especially Shah' Abbas' (Schmitz 1984; Canby 2009, 51,85.)

Turbans during Mughals: Babur uses Kulahdhar turban (Kulah cap + turban wrapped) and during Humayun, pointed hat and wrapped cloth known Taj-i-izzat', invented by Humayun. The cap had a frontal opening just like V shape. Both turbans were voluminous (of Central Asia traditions) (fig: 2a,b). Akbar have small size turban known as the atpaiti (8 lobes) turban. The headdress of Babur and Humayun was very different and according to the Central Asian climate. This may be the reason that Akbar may have adopted the small size turban from Rajput Rulers, i.e., Jodhpur rulers. Abu Fas'l describes variety of turb ans worn in the court of Akbar. Jahangir turban is to some extent larger if compared with Akbar's. It is lobular with a medium sized lobe at the front and a larger sloping downwards at the back and bound by a transverse band (fig: 4 a). While Shāhjahān turban shape was like as conch shell and broad band (of different color band of cloth) was introduced to hold it, tightly on the head. The costumes of Aurangzeb were simple and somber if compared with Jahangir and Shāhjahān. The turban became shorter, there was a significantly broader transverseband, and the turban was high from back and of an angular shape (Schimmel 2004)

The turban ornaments of princes were generally very valuable, the most luxurious being adorned with fingers of pearls. The turbans of prince and courtiers were fairly small and flat, whilst those of learned men were large and round.

\section{Turban ornaments during Mughal times}

Babur's turban is ornamented with heron's feathers in the center or white Egret feathers at the side. Humayun's turban is adorned with elegant bieds like black egret bird feather and white ostrich feathers (Parodi and Wannell, 2011) (fig: 2a,b) Akbar turbans are decorated with 
jeweled cords, generally of pearls and also ornamented with a turban ornament of jeweled flowers or a feathers of black heron's. The turban is decorated with a jeweled floral ornament (fig: 2c). Less jewelry used by Babur and Humayun but during Akbar its use increases due to the influence of Rajput in court. Even gold jewelry use increases (due to Hin du Influence). According to Thevenot, the French traveler that Jahangir wore more jewels as compared to his father. Even he wore rings in every fingers of hand. (Ojha, 1975). His turban is decorated with jeweled strings of pearls along with other precious stones, a small turban ornament at the front and a kalghi consisting of three black heron's plume with the drooping ends at the back with pearls attached at the ends (fig:3b). A difference of the turban shape is observed and this is the headgear consists of a helmet instead of a turban. The helmet is decorated with a sarpech and ostrich feathers (white) at the left side and plume of black egret feathers decorated at the end with heron's feathers at the right side (Untracht, 1997; Parodi and Wannell, 2011). The jewelry of the emperor is somewhat elaborate as compared to Akbar which was simpler.

During Shāhjahān reign, both from Persian and European sources (Travelers - Thevenot's account), one change is obviously visible. Turban is decorated with elaborate turban ornaments (sarpech) made of rubies, pearls and emeralds. A jeweled string of emeralds and pearls is looped round the turban. There is a jeweled turban hook ornament in the front at the center of the turban.

The jewelry is opulent and turban ornaments of gold combined with pearls and expensive stones. The turban is jeweled with sarpechs ending in a kalghi of a plume of black heron's feathers with the ends drooping at the back with pearls attached at the ends. A broad jeweled plate is wrapped around the turban known as the sar-patti (fig:3c).

Aurangzeb turban ornamentation is simpler and is either draped with a single or double, jeweled pearl string along with precious stones such as rubies, emeralds around the transverse band. A small ornament at the front and sarpech set with a plume of heron's feathers decorated with pearls (kalghi) at the back (fig: $3 \mathrm{~d}$ ). Jewelry seems to be less lavish and simpler if compared with Shāhjahān and Jahangir but have turban ornaments of pearls and precious stones such as rubies, emeralds and diamonds. The average height of the turban without the jewel was $13 \mathrm{~cm}$ and $19 \mathrm{~cm}$ in diameter. The turban and the jewel measured $18 \mathrm{~cm}$ high. (https://jguaa2.journals.ekb.eg/article 157413 5d81107d5dbfa776d138739f06aa10e9.pdf)

\section{Elements of Turban Ornamentation}

Chief elements to decorate a turban are the:

- The Kalghi (Turban Feathers/Indian aigrette) 
- The Sarpech (stylized Feather)

- The Sarpatti (bazuband like design for turban)

- The Turra (tassel like short strings of hanging pearls)

- Strands of Pearls

- Use of Gemstone

- Use of Gold ( nephrite jade use also found)

In Mughal commandments, ornaments of turban could only be used by royals, blood relations of chief, nobles and high officers and is considered as a graded power symbol. (Sayyed 2018).

Kalghi: Its use originated in Turkestan and came to India from there with the invasion of the Mughal in the $13^{\text {th }}$ century. The most notable Mughal variety consisted of three black occipital heron feathers (kalgi), whose use was for by the Mughal royalty. Other type of feather usually associated with Kalghi is the long, white feather that during the mating season grows as nuptial plumage on the lower back of special species of both male and female white egrets, who inhabit wetland areas.

In the Mughal miniature paintings, the feather do not stand upright but corresponding to those on the bird, extend backward, their end drooping. To exaggerate this admired downward curve, pearls, large or small as weights were attached to the feather ends.

The style of Mughal jewelry in the Akbar's era was a hybrid of Iranian and Hindu influence. The turban plume (Kalghi or Firgha) and golden bands (Sarpech) are exactly those seen in contemporary Safavid painting. Akbar followed the Iranian fashion by having his upright feather plume at the front of the turban. The upright feather held in place by a jeweled brooch at the front of Akbar turban (fig: 2c). Jahangir introduced softer, style with the plume weighted down with a large pearl.

Gelder (2018) believes that the concept of attaching pearls to the ends of actual kalghi plumes was transferred to gold gemstone-set turban sarpech ornaments stylistically designed as curving precious metal "feathers". At their terminal points was suspended a pearl, a smooth emerald, ruby of dark red round shape or a triangular shape diamond.

The Sarpech: It's literally means "forepart of head" (sar) and "screw" (pech). It is worn in Persia also, and called as "jika" or "jiqa", (meaning "crest" or else "tuft"). In Turkey it is 
"sorguch", and in Indian Urdu term sarpech. The plume like jiga was for the upper front part of the turban.

In India, there is difference in the ornament (sarpech) and the plume feather tuft (kalghi). Both were used together, (sarpech-sant-kalghi) and is considered as rank emblem among Muslim as well as and Hindu rulers. Untracht, 1997). The jigha, a turban ornament of bejeweled gold made in imitation of the feather decoration, was especially popular in the time of Jahangir and Shāhjahān; they were often made with pearls and emeralds as well.

In India design of the sarpech underwent several stages of development but the Indian gold sarpech basic structure is usually flat (hamwar). Fabricated sheet metal, when gemstone set it would probably is of hollow construction. Designs were usually symmetrical (ba-qarina), although latter forms generally favored asymmetry ( nahin ba qarina). Gemstones were normally set (jarau) only on the front face $(r u k h)$, but somewhere set with gemstones on both sides (do-rukh) to render it usable on either side. The back could be gold plain or pattern chased, or enameled (miniwari), either with a single color or in polychrome.

The original $16^{\text {th }}$ to- $17^{\text {th }}$ century sarpech unit was one piece (ek tukra) of rigid (kara) construction. Three kalaghi sarpech also exist along with one kalaghi sarpech (fig: 4a). In the $16^{\text {th }}$ to $17^{\text {th }}$ century, it took a form of single formalized, vertically rising plume that like many feathers was bent at its end towards the left (fig: $4 \mathrm{~b}$ ). Its attached gold stem was alike a feather's natural, hollow barrel. The gold version was flattened to better suit its function of preventing rotational movement (Gelder 2018). The stem was pushed into the turbans folds. The design over time underwent changes from one piece construction to additional two side units getting hinged to the main central unit.

Since from the $18^{\text {th }}$ century, two addition side parts were often added to its main part. Straight central unit, which increased the object's width, and the central unit's lower stem disappeared. With the $19^{\text {th }}$ century tendency toward jewelry elaboration, the additional units could multiply to four or six, resulting in a five or seven unit sarpech, all parts hinged joined. A sarpech of this length would extend half way around a turban's circumference and each extreme end was provided with an integral loop to which a patu'a attaches cords ending in small tassels, and by this it was tied at the turban back.

Normally the sarpech had only one central upward projecting unit (ek kalangi). By the late $18^{\text {th }}$ to early $19^{\text {th }}$ century, each hinged unit could have its own, smaller projection, the total always 
in odd numbers. Sarpeches with three projections (tin kalangi) and five projection (panch kalangi) exist (Untracht, 1997).

Designs on Sarpech also appeared with some changes with time. The late $17^{\text {th }}$ or early $18^{\text {th }}$ century, of floral sarpech designs which seem to have been inspired by contemporary textile patterns. Floral realism in sarpech and bazuband (armlet) jewelry could be heightened by the use of gemstones curved in petal and leaf forms (fig: 4c). Early $16^{\text {th }}$ and $17^{\text {th }}$ century flower units were arranged in semi-natural, open manner, often rising from stem or vase. By the early $18^{\text {th }}$ century, the floral unit was more compact, and the flowers multiplied and became more diverse. By the mid-1 $8^{\text {th }}$ century their shape assumes the unit design called a buta, used in corners

(fig: 5a).

The Sarpatti: The late $18^{\text {th }}$ century marked the development of a turban ornament, called the sarpatti (sar: head, patti: strip), that combined elements of sarpech and bazuband (armlets) (fig: $5 \mathrm{~b}$ ). This form was suggested by the initially unconventional but later common use of the bazuband as front -of-turban ornament, either alone or in combination with sarpech. The practice is seen in the mid to late $19^{\text {th }}$ century photographs.

As a synthesis of two forms, the sarpatti basically comprised of the three, five or seven hinged parts of the bazuband. A small or either large kalghi in an upstanding position is fixed on the top edge of the central part. Mostly, a single pendant unit hung beneath this, or several we re attached as a fringe to the bottom of each of the main units. Because it covered the broader area of the turban front and was visible in it's entirely, sarpati designs often reached a degree of elaboration beyond that of the bazuband, which only encircled a smaller part of the upper arm (fig: 4c).

Turra Tassels: Tassels (jhabba) consisting of short strings of pearls of equal length, gemstones and hard stones and combination of these, are commonly found in the traditional Indian jewelry and in Persia (fig: 6a)

Fashion in turban ornaments changed during Shāhjahān's reign when European portraits of rulers such a James I of England, wearing jeweled aigrettes inspired Indians to create their own version of this jewel. The aigrette turban ornament (in many va riations remained popular during 
the $18^{\text {th }}$ and $19^{\text {th }}$ centuries, when the grants of a turban ornament were no longer regulated and almost everyone of importance (regardless of religious affiliation) wore one.

\section{Indian Kalghi and Turra tassel_Source of Inspiration for European}

These two elements most closely identified with art deco jewelry — the aigrette and the tasselthe first soaring upward, the other drooping, were borrowed from two of the traditional turban ornaments used in India during Mughal times, normally as men's ornaments, but sometimes in smaller sizes also used by women.

Turra (crest worn on head; a forelock or curl), which could take the form of a stemmed rosette or a stylized enameled gold parrot with an S-shaped body and tail. From the rosette or the parrot's beak fell a pedicle cluster of short, free hanging strings of pearls, emeralds, or another gemstone, each strand often ending with contrasting gemstone bead and gold-yarn-tassel terminal. The turra was fixed to the turban by forcing the rosette stem or the parrot's S-curving tail into one side of its tight folds. Its outward curvature allowed the tassel to fall freely (fig. 6b)

\section{The European Aigrette}

During Akbar the foreigner affair started in the subcontinent. The actual examples of ea stern sarpeches found their way to Europe with Portuguese, English, French, Dutch and Danish ships because sarpeches are frequently represented in European portraits. (Especially noblewomen whose families have link with Indian trades or East India Company which shows sarpech they wear) and thus put in use by women in West.

One jeweler among many who adopted Indian sarpech design was Arnold Lulls (lives in London, 1585-1621). As a court jeweler he executed commissions for King James England and his consort, Anne of Denmark. Several portraits of James show aigrette in his hat, a British interpretation of sarpech. Anne is believed to have popularized the use of aigrette in a women's hair.

Untrach explains that Lulls's work drawing that he made around 1610 was recorded in an album and this album is in the archives of Victoria and Albert museum, London. These drawings show link between Indian and later European sarpech-aigrette design concept (fig. $6 c)$. 
Lull's design show stem of sarpech just like Indian sarpech that was inserted in the turban but later European aigrette development used a pin stem and catch at the back like brooch, to be fixed in hair and flat stem disappeared (fig: 7a). Lulls' aigrettes also follow Indian conventionalized curving feather forms ornamented with gemstones commonly used in the later $18^{\text {th }}$ century European aigrettes.

Not only European aigrette used stylized feather in their design but also were worn with actual feathers. $17^{\text {th }}$ century European men use it on hat and often with broad brim and women in hairs with hairstyles like turban by adding it with the bulk part of the hair in the $17^{\text {th }}$ and $18^{\text {th }}$ century, before French Revolution (fig: $7 b, c)$

In the $18^{\text {th }}$ century the dominant gemstone in use for aigrette and other jewelry was diamond, which was usually set in silver or white metal (thought to increase its brilliance) while the back normally was of gold and also in India (fig: 7d). As in India gemstone setting was closed at back but after that open back setting appeared and eventually replaced close-back setting. However later retained close back setting in India.

In the early $19^{\text {th }}$ century, the Empire or Neoclassical style in women dress often included a turban to which was pinned an aigrette and later also popular during world war one era.

After 1900 the introduction of platinum in European jewelry, as lightweight and invisible settings for diamonds make it more delicate. Indian client like maharajas commissioned the great jewelry houses of Paris and London to make platinum sarpech -aigrette and other jewelry. These results constitute the Euro-Indian sarpech-aigrette, which combine the formal aspects of Indian design with the technological innovations of Europe (fig: $8 \mathrm{a}, \mathrm{b}$ ). Western uses eastern designs and manipulate it according to their use (fig: $8 \mathrm{c}, \mathrm{d}$ ).

\section{Egret Feather and European Fashion}

Egret feathers have always been and still used with sarpech in India. In Europe, during $19^{\text {th }}$ and into the early $20^{\text {th }}$ century the aigrette was customarily worn with an egret-feather plume, which was also used in women hat and men military headgear (fig: 7b,c). In the early 1900's ban in egret feather trade other feathers of different birds were used like Australian emu, tail feather of African ostrich. 


\section{Gemstones Use in Turban Ornaments and their Significances}

Gems were a richness and also dignity symbol of the empire; they were also valued as protecting talismans. The stones were used for healing in different ways. Sometimes, their presence were considered enough for a cure. Gemstones carry vibrational rates. The vibrational qualities of the gemstones can further help achieve balance and awareness on physical, emotional, mental and spiritual levels (Morse, 2000), quoting Alice, (1996).

The gemstone used in the turban ornaments are as follows:

- Spinels (traditions from Persian)

- Diamond

- Rubies

- Sapphires

- Emeralds

- Pearls

Spinels have complex symbolism in Iranian culture and it was seen primarily as a metaphor of sunlight, (which was itself metaphor of divine in metaphysics). Akbar, Jahangir use spinels in their turban ornament. Also rubies were the costliest stones during the Mughal period and they were also more popularly used than diamonds or emeralds. (Nath, 1994). Rubies were valued due to its luminosity quality that it glow in the dark. Rubies name also in Quran. Rasulullah say" This gem is superior to all." According to the tradition of Ahl al Bait, wearing a ruby stops worries. Ruby cures the heart and blood diseases (Marfiat al Jawahir by Syed Ibrahim Saify). During Mughal times, standard forms for the use of emeralds developed. The greatest use of emeralds in traditional Indian jewelry is a bead of irregular form because they were made of small emerald crystals and polished with old Indian method. The resulting so called baroque form was centrally drilled in its long axis to render it suitable for use as a bead or a pendant. They often appear singly or in graduated sizes as a fringe on a crown (mukut), headdress (sarpatti), or turban ornament (sarpech).Emeralds are six-sided, eight-sided, convex or oval forms, and melon shaped beads. The hexagonal and octagonal was used in as amuletic armlet or as a necklace pendant. Emeralds were extremely popular among emperors in Mughal Court, and because of its opaque transparency they referred it as "Tears of the Moon."

In Sufism, Emerald Mountain stands for final level of spiritual aspiration and more practically according to popular belief emeralds can blind snakes and dragons. (Welch: page 163) 
During the time of Mughal, pearl is important part of jewelry. Double and triple strands of pearls were symbols of nobility by the time of Akbar at the latest. "Royal" ( $\check{s} a h v \bar{a} r$ ) pearls were of a milk like pure white color, said to be as transparent like a drop of water. Due to its shining

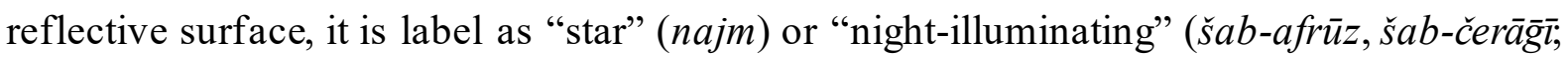
Ṭūsī, pp. 88-94, 113-14; Neẓāmī, p. 231.3).

In order to fasten the strands of pearls which were occasionally wrapped around turbans, either the sarpati was used, an oval fastening made of a precious stone, or sarpech which came in many forms. The string of pearls which was wrapped around the turban might also be interspersed with rubies. It was sometimes held in place by an emerald brooch with a large feather hanging from it, with an emerald at the back of the turban.

\section{Technique in Head Ornaments}

Technique mostly used in Mughal time is "Kundan" work, though enameling also become popular and in most turban ornaments like Sarpech, even backside is not plane but with enamel work.

During Mughal period, Rajasthan was hub of Kundankari. (Sayyid 2018) Kundan jewelry of traditional style has on one side covered with stone while elaborated and colorful meenakari on its opposite side. The complete Kundankari technique depends on its skillful gems setting in solid gold. Holes were cut for the gems and engraving is carried out. Later, the, pieces are enameled. The core of the ornament is made out of lac, a natural resin. Later, lac is inserted into the hollow parts and is then visible from the front, through the holes left for the gems. Refined gold or kundan is used to cover the lac. Gems are then pressed in the kundan. More kundan is applied to increase the joint strength and for smooth look. Style of sarpech varies according to the area.

\section{Conclusion}

In Mughal society, a noble was expected to maintain a standard of dress and ornamentation for himself, his family and his servants that reflected his social and political standing and although turbans have been used in India since antiquity but were especially prominent during Mughal times. Even the Gems used by Mughal were for special purposes along with ornamentation purposes. Though there are varieties of Mughal head ornaments but Turban ornaments have more varieties that throughout exists in different design. Sarpech design developed through centuries. Initial Kalghi with brooch used than a single unit Sarpech later two additional side 
pieces were added to the straight central part. Emphasis on intricate jewelry design and enlarged and later sarpech were large enough that it covers the half turban. Though Europe innovative Jigha improves the design but they took inspiration from the eastern sources. The Saprech designs also helps in the European aigrette design concept that witnessed in European designer drawings. In the end the turra with stands of pearls serves as an additional jewelry along with kalghi and Sarpech, sarpeti and thus heavy turban jewelry became trend of Mughals. This depict the wealth and status and were embodied with gems as spinels as metaphor of sunlight, rubies as source of cure, emeralds with spiritual qualities and pearls as symbol of royalty. Mostly gems were embeded with Kundankari work.. Turbans were worn by men of all social strata, from ruler to peasant and use of jewelry according to the status remained fashion in later maharajas also but in form of Euro-Indian sarpech-aigrette, with combination of local designs with the technological innovations of Europe. Still it is commonly worn on special occasions such as wedding which includes a turban with an attached sarpech ornament.

\section{List of Figures:}

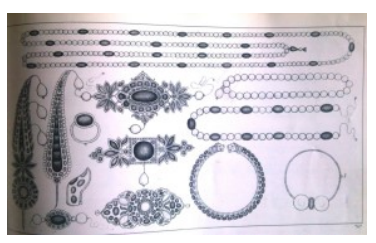

Figure 1: Watercolor paintings from the Gentil Album showing Mughal ornaments for men, in Victoria and Albert Museum, London (IS 25-1980) (Source: Untracht, Oppi. Traditionlal Jewelry of India., page: 345 )
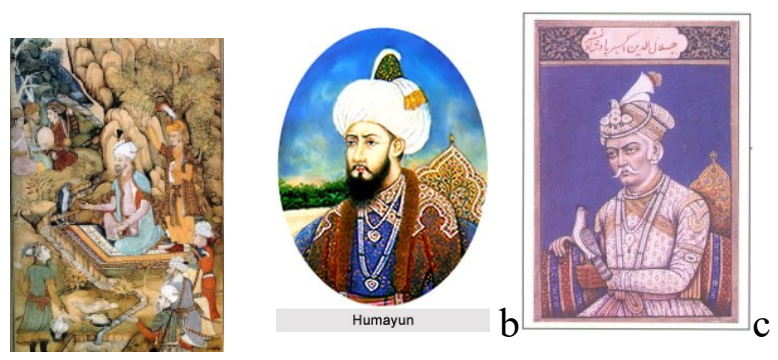

Figure 2: (a): Babur voluminous turban (b): Humayun turban with Central Asian Tradition (c) Akbar turban contains upright feather held in place by a jeweled brooch (http://www.indiapicks.com/Indianart/Images MP/Mughal Akbar.jpg) 

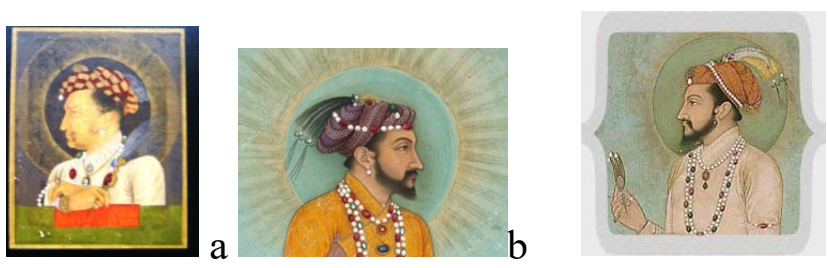

(c)

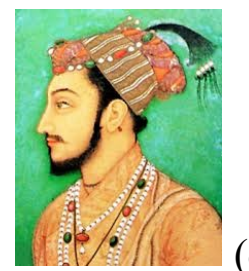

(d)

Figure 3: (a): Jahangir holding a turban Jewel, (b) kalghi consisting of three black heron's plume feathers with the ends drooping at the back with pearls attached at the ends (c) Shah jahan; sarpechs ending in a kalghi of feathers with the ends drooping at the back with pearls and sarpati and holding tin kallgi sarpech. (d): Aurangzeb: Kalagi and sarpech
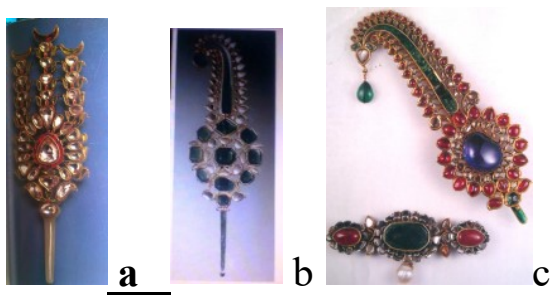

Figure 4: a) Delhi, 17th century Aigrette with three plume ( tin kalangi sarpech) in white nephrite, carved in deep relief and set in kundan style (b): Probably second half of $17^{\text {th }}$ century, Stylized feather was bent at its end towards the left (c): Murshidabad, West Bengal, c,1757 Gold Sarpech, and armlet showing bent feather and three hinged bazuband
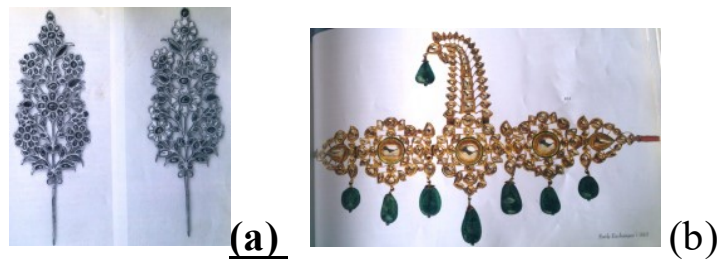

Figure 5: (a)Delh, $18^{\text {th }}$ century , do rukh, symmetrical designed Mughal or Rajput design, floral unit (buta design ) ( b) Jaipur, Rajasthan, $19^{\text {th }}$ century, five part hinged aigrette (ek Kalangi Sarpech) gold open work, set with foiled diamonds kundan style and eight drilled pendent emeralds, the reverse is polychrome enameled.
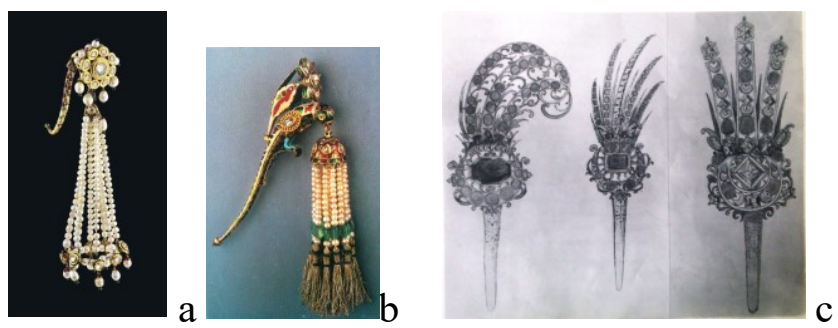
Figure 6: (a) An enameled diamond-set and pearl turban ornament (turra) Probably Hyderabad, Mughal India, 19th century (b): Jaipur, Rajasthan, Enameled gold side of turban ornament (turra) (c) London, England, Three record or design drawings in pencil, pen and ink, colored wash and gold from work book Arnold Lulls (Source: Untracht, Oppi. Traditionlal Jewelry of India., page: 382-5) http://www.pinterest.com/eliza1960/mughal-empire-jewels/)
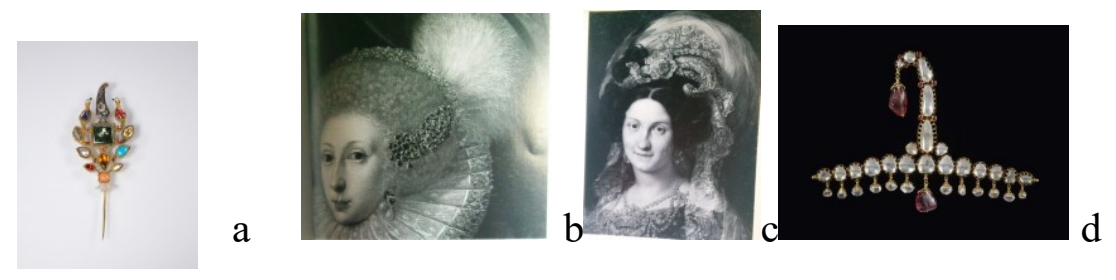

Figure 7: (a) Pin like sarpech, (b) England, Elizabeth, (c) Spain, portrait of Queen Maria Christina, both showing stylized feather design like sarpech.), (d) Diamond turban ornament (sarpech), India, circa 1875-1900(Source: Untracht, Oppi. Traditionlal Jewelry of India., page: 385, http://www.asianartnewspaper.com/article/beyond-extravagance-al-thani-collectionearly-mughal-jewellery
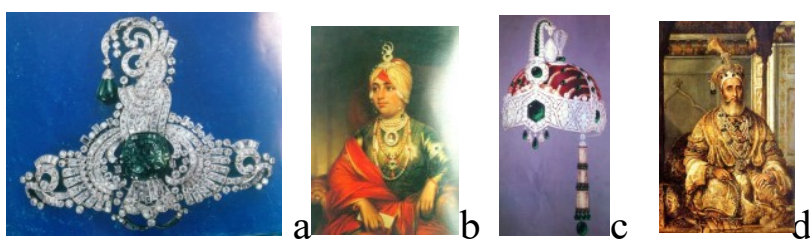

Figure 8: (a) Paris, France, 1930, Diamond and emerald-set platinum sarpech-aigrette, made for Indian client in Europen workshop (b): Punjab, Maharja wearing an aigrette with three plumes ( tin kalagi sarpech) of Europen stlye.(c) : Paris, France, c 1925, the sarpech, sarpati and tura have combined in one continuous ornament. Indian turban is converted in to French cloche hat, (d) Bahadur Zafar Shah II, 17th and last Mughal Emperor of India, tura tassel, sarpech with Kalagi and sarpati on his hear ornaments is shown. (Source:http://www.internetstones.com/agra-diamond-famous-jewelry.html) (Source: Untracht, Oppi. Traditionlal Jewelry of India., page: 386) 


\section{References:}

1. III, Joseph M. Dye, 2001. THe Arts Of India. Italy: Philip Wilson Publisher.p 87

2. Schimmel, Annemarie, 2004. . The Empire Of The Great Mughals HIstory, Art and Culture. London: REAKTION Books LTD. p 23-56

3. Stronge, Susan. n.d. Made for Mughal Emperors Royal Treasures From Hindustan. Delhi: Lustre Press, p.87,105

4. Untracht, Oppi. 1997. Traditionlal Jewelry of India. London: Thames and Hudson, page 382-345.

5. Bernadette, Van Gelder 2018. Traditional Indian Jewellery. pdf

6. Marshman, John Clark. 1863. "Nadir Shah". The History of India. Serampore Press. p. 199.

7. Sayed, Dr Nafisa Ali. Mughal Jewellery . A Sneak Peak of Jewellery Under Mughals

8. Canby, Sheila R. 2000. Princes, Poets\& Paladins: Islamic Indian Paintings from collection of Prince and Princess Sadruddin Aga Khan. London. p 56,179-82

9. Fuess, Albrecht,2008. "Sultans with Horns: The Political Siginificance of Headgear in the Mamluk Empire," Mamluk Studies review 12 . pp 71-94

10. Blair, Sheila S.,1995. A Compendium of Chronicles: Rash' d al-Din's Illustrated History of the World (Oxford) pdf

11. Necipoglu, Gulru. 1997. "Gardens in the Time of the Great Muslim Empires" theory and design. Leiden: Brill . pp 32-71 pdf

12. Welch, Stuart Cary. 1985 Art and Culture. New York: Metropolitan Museum of Art,.p.163.

13.https://www.academia.edu/13435409/Turban_and_Crown_An_Essay_in_Islamic_Civ ilization

14.http://www.indianetzone.com/1/jewellery_moghul_period.htm

15. http://www.diamonds.net/Magazine/Article.aspx?ArticleID=44047\&RDRIssueID=1 1 3

16. http://books.google.com.pk/books?id=N7sewQQzOHUC\&pg=PA171\&lpg=PA171\& ots $=3 \mathrm{NSbKZMzm} 3 \&$ focus $=$ viewport $\& \mathrm{dq}=$ turban + ornaments + of + mughal\&output $=\mathrm{ht}$ ml_text

17. http://www.iranicaonline.org/articles/color-pers-rang\#pt2

18. http://www.durrenajaf.com/upload/51311674462c0.pdf

19. http://shodhganga.inflibnet.ac.in/bitstream/10603/13623/10/10_chapter\%204.pdf 